Research Article

\title{
Experimental and Numerical Analysis of Hollow and Solid Reinforced Concrete Piers under Static and Impact Loadings
}

\author{
Pengfei Yao, Junyu Zhu, Lu Zhu (D), Hai Fang, and Changgen Qian
}

College of Civil Engineering, Nanjing Tech University, Nanjing 211816, China

Correspondence should be addressed to Lu Zhu; zhulunjut@njtech.edu.cn

Received 4 March 2021; Revised 25 May 2021; Accepted 19 July 2021; Published 27 July 2021

Academic Editor: Zengshun Chen

Copyright $\odot 2021$ Pengfei Yao et al. This is an open access article distributed under the Creative Commons Attribution License, which permits unrestricted use, distribution, and reproduction in any medium, provided the original work is properly cited.

Collision on reinforced concrete (RC) piers by moving vessels or vehicles is a significant issue. This paper presents the static and impact behavior of RC piers with different hollow ratios. Three specimens were statically tested to obtain the load-displacement response. Low-velocity collision on eleven RC piers was conducted under the same velocity of $2.42 \mathrm{~m} / \mathrm{s}$. The damage process, failure mode, and force response were comprehensively analyzed. The experimental results indicate that the hollow ratio plays a significant role in the failure mode and ultimate load of RC piers under static and impact loadings. For RC piers with a hollow ratio of 0 and 0.4 , the global failure dominated the damage process. However, failure of piers with a hollow ratio of 0.6 was governed by the local damage near the loading point. The static load capacities of the RC piers with a hollow ratio of 0.4 and 0.6 were $1.27 \%$ and $60.5 \%$ smaller than that of the solid pier, respectively. RC piers with a higher hollow ratio or lighter drop weight suffer smaller peak impact force. The increase of the longitudinal reinforcements leads to a promotion of the peak and mean impact force. Furthermore, the numerically predicted failure modes and impact load response show satisfactory agreement with the experimental results.

\section{Introduction}

Reinforced concrete (RC) structures are commonly used in bridge engineering across the world. Bridge piers are vulnerable to accidental impacts by moving vessels or vehicles, which may trigger localized damage or even total collapse of bridge structures [1-3]. The structural safety under impact load should be carefully assessed. The impact load due to vessel or vehicle collision is characterized by a high intensity but a short duration. Stress wave propagation, strain rate effect, and inertial effect should be considered in the complex dynamic analysis for RC structures [4]. Therefore, to ensure the structural efficiency and promote performance level during the whole life cycle, it is necessary to investigate the impact behavior of RC structures.

Assessments of the dynamic behavior of solid RC structures by experimental, numerical, and analytical techniques have been well documented in the literature. Fujikake et al. [5] carried out drop hammer impact tests and nonlinear analysis on RC beams considering variations of drop heights and longitudinal rebars. The amount of reinforcements had a significant effect on the failure modes. The dynamic response and impact force-time histories were mainly affected by the drop height and the flexural rigidity of RC beams. Kishi and Mikami [6] designed a great number of statically flexure-controlled RC beams with different cross section dimensions, clear spans, and reinforcement ratios. A performance-based design formula was proposed based on the results of the drop weight impact test. Zhao et al. [7] proposed a simplified method to predict the peak force and midspan displacement of simply supported RC beams subjected to impact loading. Guo et al. [8] investigated the dynamic deflection response of simply supported and fully clamped RC beams by theoretical and numerical methods. The results show that the maximum deflections are almost proportional to the input impact energy. Demartino et al. [9] conducted the horizontal impact test on shear-deficient RC piers with two boundary conditions, i.e., one fixed end and another cantilever or simply supported end. Obvious diagonal crack originated from column foot to the impact 
point, indicating a brittle shear failure mode. Fan et al. [10] performed the drop hammer test, compression test, and numerical analysis of circular RC columns to evaluate the residual axial capacity after impact. The residual capacity depended on the deformation and failure mode due to impact load. Ye et al. [11] investigated the effect of the slenderness ratio, reinforcement ratio, and axial compression ratio on the impact force and dynamic response of $\mathrm{RC}$ columns by a horizontal impact test machine. Results showed that the higher column slenderness ratio led to a larger value of the generalized ratio of peak impact force and longer impact duration. The enhancement of the reinforcement ratio and axial compression ratio could increase the average impact force. The existence of axial load relieved the residual deformation of the column. Zhou et al. [12] experimentally compared the impact response of RC piers with ordinary steel bars and stainless-steel bars under the protection of closed-cell aluminum foam. The results show that the impact forces of the stainless-steel RC piers were greater than that of ordinary RC piers, and the use of stainless-steel bars increased the possibility of shear failure modes. Yilmaz et al. [13] carried out the drop weight test to determine the influence of the axial load, impact energy, and shear reinforcement spacing on the impact performance of square RC columns. Wei et al. [14] conducted an experimental and numerical study of RC and ultra-high performance concrete (UHPC) columns under low-velocity impact loading. The results show that RC columns experienced brittle shear failure, while UHPC columns only showed minor flexural damage. $\mathrm{Wu}$ and $\mathrm{Xu}$ [15] experimentally evaluated the damage degree of stainless-steelreinforced concrete piers with different longitudinal bars under four impact velocities and found that increasing the reinforcement ratio can obviously reduce the damage level.

In terms of vessel or vehicle impacts on RC bridge piers, numerical methods are widely used due to the efficiency and economic benefit. Sha and Hao $[16,17]$ conducted the pendulum impact tests and numerical simulations of circular RC piers under barge collision. Structure-related and load-related factors such as pier diameter, pier height, impact location, velocity, and mass were carefully examined. An empirical formula was proposed to calculate the barge impact force. Wang et al. [18] proposed a period-dependent impact factor method to estimate the dynamic response of bridge piers under vessel collision. The precision was validated by dynamic time history method of two example bridges. Sharma et al. [19] proposed the performance-based procedure to evaluate the dynamic shear force capacities of RC columns corresponding to performance levels. Li et al. [20] conducted a simulation analysis of vehicular collision on seismic designed RC piers and evaluated the damage level based on the damage index considering the pier diameter and shear-span ratio. Auyeung et al. [21] introduced a damage ratio index to correlate the damage level to target performance level in the design of bridges under vehicle collision. It was found that pier diameter governed the global failure type, and the transverse reinforcement ratio determined the local damage. Chen et al. [22] simulated the failure process of three-column RC piers under vehicle collision and proposed a safety assessment method to determine the shear failure. Do et al. [23] numerically investigated vehicle collision on RC bridge columns. The vehicle impact force, the dynamic shear capacities, and failure modes of RC columns can be predicted by a simplified analytical model.

Hollow RC structures are widely used as bridge piers owing to the proper balance between performance and cost $[24,25]$. It is necessary to evaluate the influence of crosssectional changes on structural safety under different load cases [26, 27]. However, few investigations on the low-velocity impact responses of hollow RC structures have been found in the literature. Most studies have focused on the seismic performance of hollow RC piers. Yeh et al. [28] conducted an experimental investigation on the seismic behavior of rectangular RC piers with different hollow ratios. The results showed that the main crack patterns of $\mathrm{RC}$ members were bending failure, bending-shear failure, and shear failure. Lee et al. [29] investigated the seismic behavior of circular hollow RC columns under cyclic loading. The damage process of flexure-controlled columns and compression-controlled columns varied, due to the different neutral axis location at failure. Qi et al. [30] performed the shaking table test of three scaled rounded rectangular hollow piers. Unlike the column response in common semistatic test, a second plastic hinge region appeared near the midspan of the pier. The increased volumetric stirrup ratio led to a better seismic performance.

Several investigations have been conducted on the lateral impact behavior of other hollow piers, such as partially concrete-filled steel tubular columns, concrete-filled doubleskin steel tube columns, and hollow-core fiber-reinforced polymer (FRP) concrete-steel columns. Zhu et al. [31] experimentally and numerically investigated the lateral impact performance of hollow and partially concrete-filled steel tubular columns. The results indicated that the concrete filling height had a great influence on the local impact resistance and global crack patterns. Wang et al. [32, 33] experimentally and numerically investigated the influence of some key factors (such as impact height, hollow ratio, axial load) on the impact force and displacement response of concrete-filled double steel tubular members. An empirical formula for dynamic increase factor was proposed to calculate the lateral impact capacity. The results showed that the hollow ratio was the main parameter influencing the peak force and the suggested value for the hollow ratio was less than 0.7. Li et al. [34] conducted the field blast test, axial compression test, and numerical simulation to investigate the postblast behavior of concrete-filled double-skin steel tube columns. Damage could be rapidly evaluated by the proposed empirical formula calculating the residual axial capacity. Wang et al. [35] investigated the influence of axial force on impact performances of concrete-filled steel tubular members and proposed an analytical method to calculate the deflection by equivalent single degree of freedom (SDOF) model. Aghdamy et al. [36] analyzed the impact response of concrete-filled double-skin steel tube columns by numerical methods. The diameter-to-thickness ratio of outer tube, the slenderness ratio, and the hollow ratio were the key 
structure-related parameters affecting the impact response. Wang et al. [37] performed the drop hammer test of FRPUHPC-steel double-skin tubular columns. The abovementioned literatures indicated that the hollow ratio had a significant influence on the impact response of concrete members.

Overall, most of the existing studies focus on the impact performance of solid RC beams and piers. However, the considerable number of studies on impact performance of hollow columns with steel-concrete, steel-concrete-steel, and FRP-concrete-steel materials can provide useful reference. However, there is limited experimental data related to the low-velocity impact behavior of hollow RC columns. Thus, the objective of this research is to evaluate the static and impact performance of RC piers with different hollow ratios. The vertical static tests on three RC piers were firstly carried out. The damage process, failure mode, and the loadmidspan displacement were fully discussed. The impact tests on eleven rectangular RC piers were subsequently conducted. The design variables included the hollow ratio, the amount of longitudinal reinforcements, and the impact energy. Effect of these parameters on the failure mode and load response was comprehensively analyzed. Numerical models of the impact test were further developed using ANSYS/LS-DYNA. The simulated failure modes and load histories were compared with the experimental results.

\section{Experimental Program}

Vertical static tests and low-velocity impact tests were conducted. The test specimens, experimental setup, and layouts of instrumentation are discussed in detail.

2.1. Test Specimens. A total of nine hollow RC piers and five solid RC piers were cast with the same materials. Figure 1 presents the detailed dimensions of test specimens. All RC piers were $1550 \mathrm{~mm}$ in length, $300 \mathrm{~mm}$ in height, and $200 \mathrm{~mm}$ in dimension. A RC footing with a cross section of $410 \mathrm{~mm} \times 480 \mathrm{~mm}$ was built to create fully fixed boundary condition. The RC piers were designed according to two variables: the hollow ratio $\eta$ and the amount of longitudinal reinforcements $N$. The hollow ratio is defined as the ratio of $A_{i}$ to $A$. The parameters $A_{i}$ and $A$ are the cross-sectional area of the inner void and the solid pier, respectively. The wall thickness for two types of hollow piers are $44 \mathrm{~mm}$ and $27 \mathrm{~mm}$. The layouts of the reinforcements on the cross section are shown in Figure 2. The diameter of longitudinal and shear rebars was $6 \mathrm{~mm}$ for all specimens. The spacing of shear reinforcements was $100 \mathrm{~mm}$. The yield strength of all reinforcements was $310 \mathrm{MPa}$. The cubic compressive strength of concrete was $30 \mathrm{MPa}$.

Three specimens were tested under static loading. The impact test involved eleven piers, including three groups, i.e., DA group with $\eta=0$, DB group with $\eta=0.4$, and DC group with $\eta=0.6$. Details of the specimens are summarized in Table 1. Three main parameters including the hollow ratio $\eta$, the impact energy $E$, and the total number of longitudinal reinforcements $N$ were considered. The following naming rules are used to characterize each specimen. The letter "S" or " $D$ " denotes that the specimen is under static or dynamic loading. The letters " $\mathrm{A}$," "B," and "C" represent a hollow ratio of $0,0.4$, and 0.6 , respectively. The numeric value " 20 " or " 30 " denotes that $N=20$ or $N=30$. The last Roman numerals "I," "II," and "III" denote that the mass of the impactor $(M)$ is $230 \mathrm{~kg}, 330 \mathrm{~kg}$, and $430 \mathrm{~kg}$, respectively. The impact height was designated to be constant as $0.3 \mathrm{~m}$; therefore all specimens had an identical impact velocity with a value of $2.42 \mathrm{~m} / \mathrm{s}$. Thus, the impact energy was changed by adjusting the drop weight.

2.2. Test Setup and Instrumentation. Figures 3(a) and 3(b) show the experimental setup for the vertical static test and low-velocity impact test of the RC piers, respectively. All piers were fixed at one end and simply supported at the other end. A steel beam placed on the concrete base was bolted to the floor to achieve the fixed boundary condition. A steel roller-bearing was installed at a distance of $150 \mathrm{~mm}$ from the free end of the pier, as depicted in Figure 4(a). For impact loading, an additional top steel roller-bearing connected to the bottom one was used to prevent the pier from vertical bouncing.

In the static test, a 100-ton Jack was employed to exert vertical force with an interval of $5 \mathrm{kN}$. A T-shape steel loading head was placed at the midspan to transfer local linear force to each specimen. The $40 \mathrm{Cr}$ steel loading head had a semicircular nose with a radius of $25 \mathrm{~mm}$, as illustrated in Figure 4(b). The vertical deflection at the midspan was measured by a YHD displacement sensor with a range of $200 \mathrm{~mm}$. In addition, another two small range displacement sensors were fixed at the supported ends.

The low-velocity dynamic test was conducted by a drop hammer impact system in Nanjing Tech University, China. The drop hammer consists of a hammer body with adjustable weight and a changeable hammer head. The hammer head for the impact test was the T-shape one used in the static test. The mass of the hammer head is $30 \mathrm{~kg}$. The mass of the hammer body can vary from $200 \mathrm{~kg}$ to $1200 \mathrm{~kg}$ with an interval of $50 \mathrm{~kg}$. Therefore, the selected drop weights were $230 \mathrm{~kg}, 330 \mathrm{~kg}$, and $430 \mathrm{~kg}$. The test results were automatically recorded at a sampling rate of $400 \mathrm{kHz}$.

\section{Test Results and Discussion}

\subsection{Response under Static Loading}

3.1.1. Crack Patterns. Figure 5 presents the failure modes of specimens under static loading. Damage was concentrated in the midspan area. The experimental results showed that the wall thickness of concrete pier played a significant role in the damage process and failure mode. For specimen SA20, one vertical crack initially occurred near the lower edge of the pier, with the corresponding load being $100.9 \mathrm{kN}$. The flexural crack then developed and propagated vertically toward the upper edge. Meanwhile another vertical crack was observed near the initial flexural crack. Since the maximum bending moment occurred at the midspan, the flexural cracks were recognized around the middle of the 




Figure 1: Sketch view of the RC piers (unit: $\mathrm{mm}$ ).



(a)

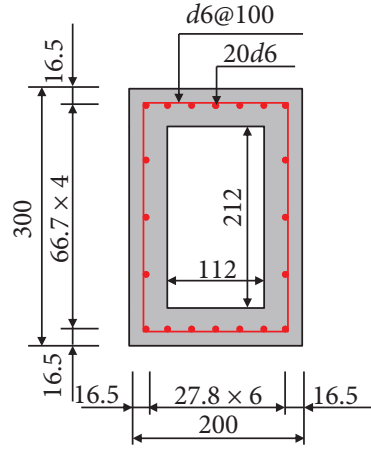

(b)

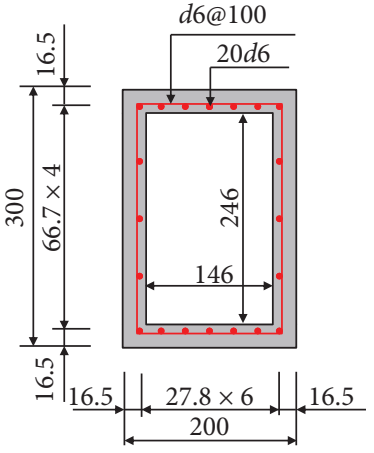

(c)

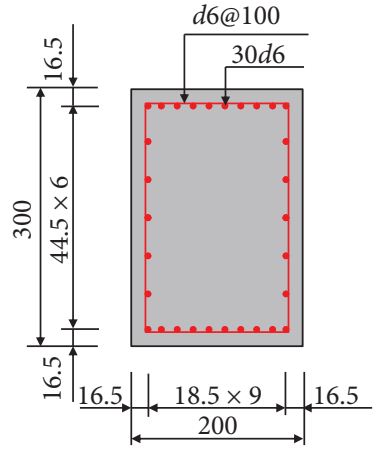

(d)

Figure 2: Cross-sectional arrangements of steel rebars (unit: mm). (a) $\eta=0, N=20$. (b) $\eta=0.4, N=20$. (c) $\eta=0.6, N=20$. (d) $\eta=0, N=30$.

TABLE 1: Details of the specimens and the experimental results.

\begin{tabular}{|c|c|c|c|c|c|c|c|c|}
\hline Specimen & & $N$ & $M(\mathrm{~kg})$ & $E(\mathrm{~J})$ & $F_{p}(\mathrm{kN})$ & $T_{d}(\mathrm{~ms})$ & $F_{\text {ave }}(\mathrm{kN})$ & Failure mode \\
\hline \multirow{3}{*}{ Static test } & SA20 & 20 & & & 142.73 & & & Bending failure \\
\hline & SB20 & 20 & & & 140.91 & & & Bending and local failure \\
\hline & SC20 & 20 & & & 56.36 & & & Local failure \\
\hline \multirow{11}{*}{ Dynamic test } & DA20I & 20 & 230 & 676 & 102.59 & 10.3 & 28.67 & No obvious damage \\
\hline & DA20II & 20 & 330 & 970 & 163.85 & 12.8 & 57.04 & Bending failure \\
\hline & DA20III & 20 & 430 & 1264 & 185.90 & 11.1 & 52.05 & Bending failure \\
\hline & DA30III & 30 & 430 & 1264 & 254.20 & 11.0 & 74.08 & Bending failure \\
\hline & DB20I & 20 & 230 & 676 & 80.48 & 10.4 & 33.88 & Shear failure \\
\hline & DB20II & 20 & 330 & 970 & 91.84 & 12.0 & 50.65 & Bending-shear failure \\
\hline & DB20III & 20 & 430 & 1264 & 130.27 & 14.7 & 50.24 & Bending-shear failure \\
\hline & DB30III & 30 & 430 & 1264 & 133.97 & 12.0 & 74.79 & Bending-shear failure \\
\hline & DC20I & 20 & 230 & 676 & 40.29 & 14.2 & 20.00 & Local failure \\
\hline & DC20II & 20 & 330 & 970 & 63.78 & 18.4 & 24.25 & Shear and local failure \\
\hline & DC30I & 30 & 230 & 676 & 58.68 & 11.8 & 28.77 & Local failure \\
\hline
\end{tabular}

pier. Another two diagonal cracks occurred at the half span near to the fixed end, whereas no oblique cracks were observed at the half span near to the simply supported end. The main reason was the different shear force distribution. The cracks became wide when the load increased. The bending crack eventually developed as the primary crack. Longitudinal steel rebars in the textile region broke after the maximum load. Hence, the flexural crack width and the midspan displacement continued to grow. The failure was governed by two vertical cracks at the midspan, indicating specimen SA20 exhibited the overall bending failure mode.

Crack distribution of specimen SB20 was similar to that of specimen SA20. However, obvious spalling of the concrete cover was observed in the front and rear side of the pier. Concrete in the upper compression region was crushed, while fracture of reinforcements in the lower tensile zone did not happen. Thus the final main flexural width of specimen SB20 was much smaller than that of specimen SA20. The specimen with a hollow ratio of 0.4 exhibited the overall bending failure mode, as well as the local damage mode.

For specimen SC20, a tiny vertical crack and a small oblique crack originally emerged at the bottom side of the pier. The concrete beneath the hammer head was partially crushed at a load of $40 \mathrm{kN}$. As the load continued to increase, the bottom cracks expanded slowly and failed to develop as main cracks. However, the upper crushed area obviously 


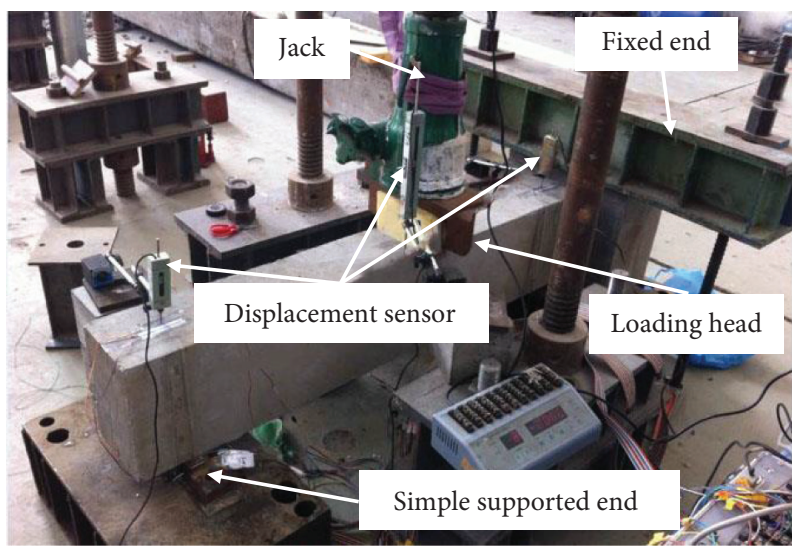

(a)

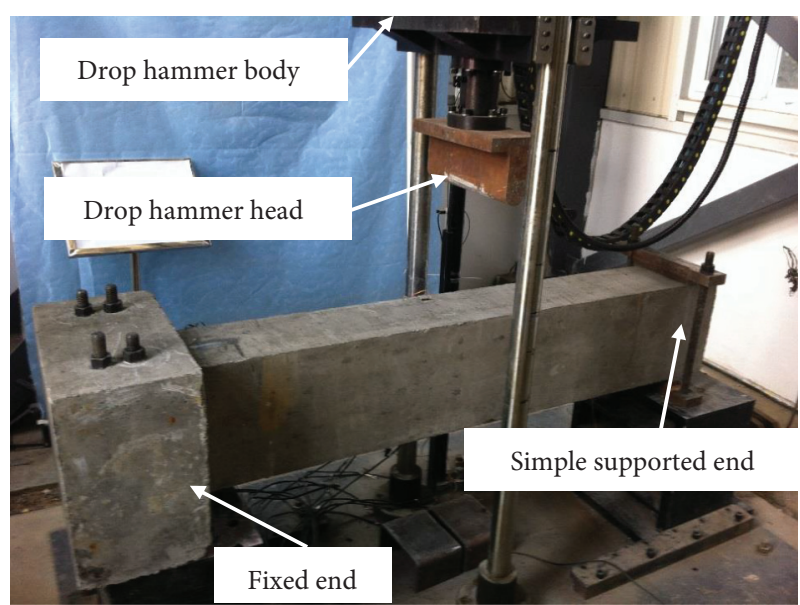

(b)

Figure 3: Test setup. (a) Static test. (b) Impact test.
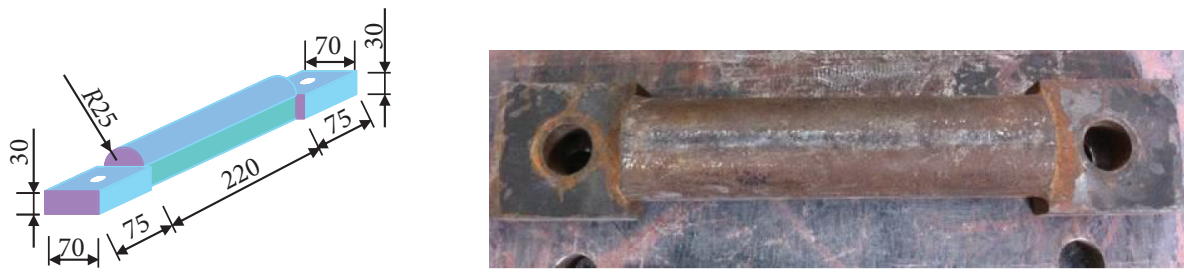

(a)
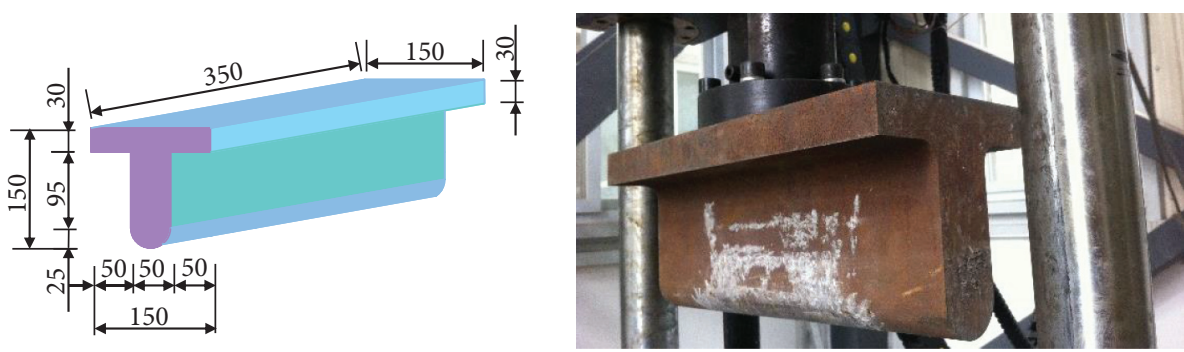

(b)

FIGURE 4: Details and photos of the steel roller-bearing and drop hammer head (unit: $\mathrm{mm}$ ). (a) The steel support. (b) The drop hammer head.

enlarged, indicating local failure developed into the main damage. Moreover, indentation into concrete near the load point of specimen SC20 was severe, due to thin wall thickness and small local stiffness.

3.1.2. Load-Midspan Displacement Relationships. The loadmidspan displacement curves obtained from static tests are illustrated in Figure 6 . The characteristic points such as ultimate load and the corresponding displacement are identified. When the concrete crack firstly appeared on specimen SA20, the load was $100.91 \mathrm{kN}$ and the midspan displacement was $1.68 \mathrm{~mm}$. Compared with specimen SA20, the cracking loads of specimens SB20 and SC20 were reduced by $23.4 \%$ and $62.4 \%$, respectively. Meanwhile the corresponding midspan displacement was increased by $73.8 \%$ and decreased by $18.4 \%$, respectively. The elastic stiffness of the pier seems to have a great influence on the static cracking performance. The larger the elastic stiffness, the bigger the cracking load. The ultimate static loads for specimens SA20, SB20, and SC20 were $142.73 \mathrm{kN}, 140.91 \mathrm{kN}$, and $56.36 \mathrm{kN}$, respectively. Results indicate that a relatively small hollow ratio (i.e., $\eta=0,0.4$ ) has little effect on the static load capacity. Nevertheless, an excessive increase in the hollow ratio (i.e., $\eta=0.6$ ) can significantly reduce the ultimate load.

The vertical load of specimen SA20 dropped from $120 \mathrm{kN}$ to $104 \mathrm{kN}$ due to the fracture of bottom tensile reinforcements. Then the vertical load remained basically the same, but the midspan deflection increased from $16.3 \mathrm{~mm}$ to $30.36 \mathrm{~mm}$, revealing a platform in the load-displacement curve. For specimen SC20, the local crushing of concrete and the buckling of reinforcements contributed to the rapid decrease of the load curve. In addition, the load-displacement curve of specimen SC20 showed a rising tendency at the final stage. This abnormal rising was mainly caused by 

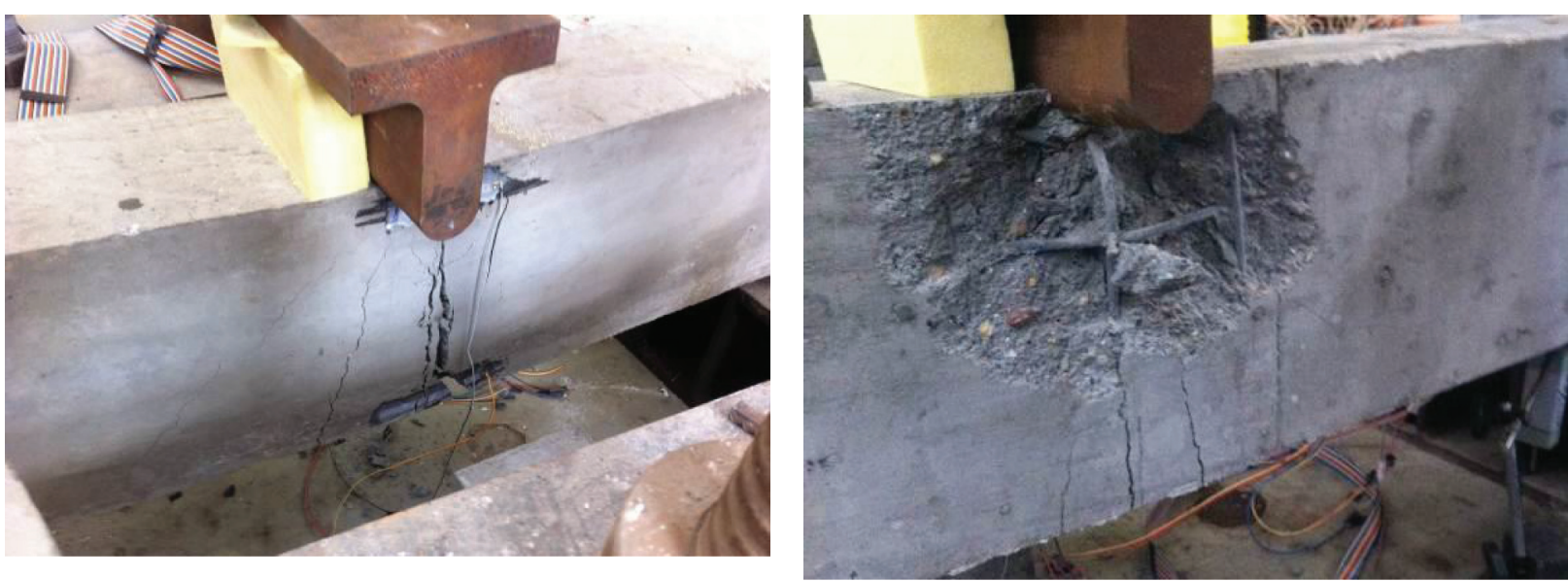

(a)

(b)

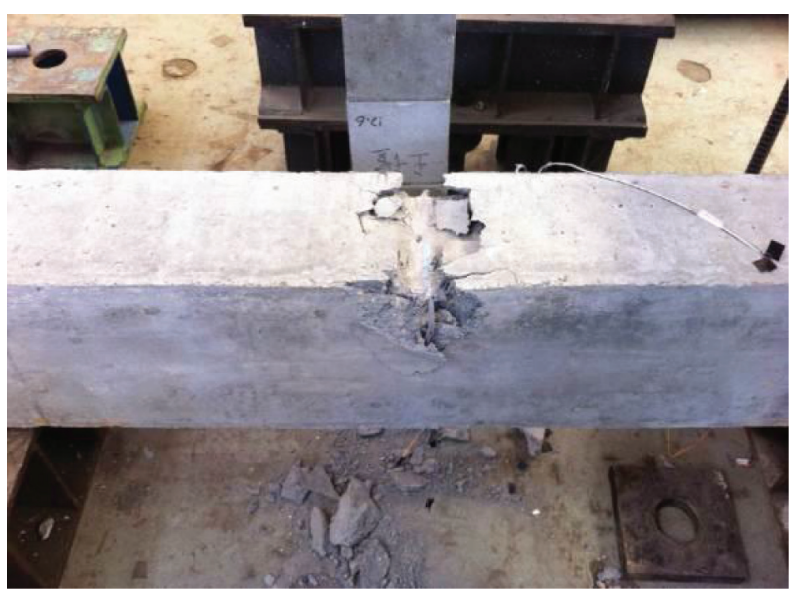

(c)

FIGURE 5: Failure modes in static loading test. (a) SA20. (b) SB20. (c) SC20.

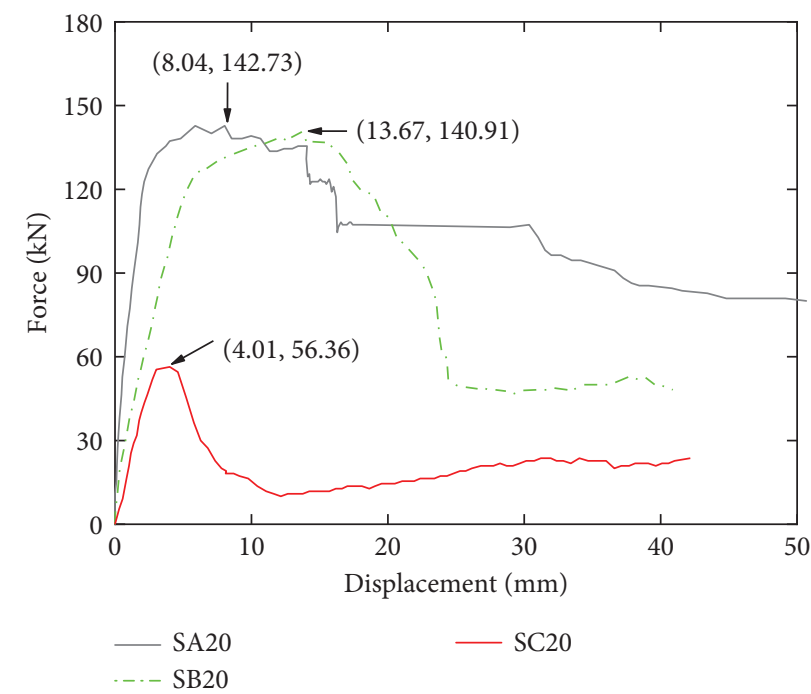

FIgURE 6: Static load-midspan displacement curves of specimens. 
resistance from the upper rebars after the full crushing of concrete near the loading point. Based on the shape of the load-displacement curves, specimens SA20 and SB20 generally exhibited a certain ductility, while specimen SC20 showed the brittle behavior.

\subsection{Response under Impact Loading}

3.2.1. Failure Mode. Damage of solid piers under impact loading is shown in Figure 7. Specimen DA20I had no obvious damage, except for slight concrete cover spalling in the local region underneath the drop hammer. Other specimens of DA group exhibited narrow vertical cracks initiating from the underside. Specimen DA30III possessed more tensile longitudinal reinforcements than specimen DA20III, indicating minor bending cracks.

Figure 8 demonstrates the crack patterns for specimens of DB group subjected to impact loading. All specimens except for DB20I exhibited vertical cracks as well as diagonal shear cracks, indicating bending-shear failure. The shear cracks fully developed and located within one-quarter to one-half span from the fixed end. Meanwhile another two parallel shear cracks originating from the fixed end were observed on specimen DB30III. This is most likely due to the increase in longitudinal reinforcements, resulting in higher bending capacity and being inclined to shear damage. Since the lowest impact energy is of specimen DB20I, only oblique cracks were observed as shown in Figure 8(a).

Figure 9 displays the failure modes of specimens of DC group under impact loading. Both indentation into concrete near the impact region and local crushing of concrete appeared on all specimens. This can be attributed to the fact that the RC pier with a hollow ratio of 0.6 has a small area of concrete, i.e., a small local stiffness; therefore the structure response is concentrated to the local region near the load point. It is similar to the response of specimen SC20 under static loading. In addition, specimen DC20II exhibited two diagonal shear cracks.

To sum up, the hollow ratio of RC piers played an important role in the failure behavior under impact loading. Failure modes for all piers are listed in Table 1. RC piers with a hollow ratio of 0 and 0.4 generally exhibited the global failure modes, whereas failure of hollow piers of DC group was governed by local damage near the drop hammer. Solid piers with drop weights of $330 \mathrm{~kg}$ and $430 \mathrm{~kg}$ failed in a flexural mode. Specimens of DB group with hammer weights of $330 \mathrm{~kg}$ and $430 \mathrm{~kg}$ exhibited the bending-shear failure modes.

3.2.2. Impact Force. The impact force mainly depends on the impact energy, the local stiffness of the contact surface, and the global stiffness of the specimen. Figure 10 demonstrates time histories of the impact force for specimens with different hollow ratios. Specimens DC20II and DC30I exhibited distinct impact load-time history curves. The impact load near the peak value was relatively steady. However, the impact load curves for other specimens developed the same trend. The impact force sharply increased to the first peak value, then reduced rapidly, developed several other peak values, and finally reduced to zero. The first peak lasted about $2 \mathrm{~ms}$. The total duration time ranged from $10.3 \mathrm{~ms}$ to $18.35 \mathrm{~ms}$.

The peak impact force $F_{p}$, the total duration time $T_{d}$, and the average impact force $F_{\text {ave }}$ are tabulated in Table 1 . The values of three physical quantities can be obtained from the impact force-time curves. $F_{p}$ is the transient maximum value of the impact force. $T_{d}$ is the total duration of the load curve. $F_{\text {ave }}$ is the average value of the impact force during the time length of $T_{d} . F_{\text {ave }}$ is defined as the ratio of the area enclosed by the force-time curve to the duration time.

It can be seen from Figure 10 and Table 1 that drop weight had a significant effect on the transient peak load. Compared with specimen DA20I, the maximum impact force for specimens DA20II and DA20III was increased by $59.7 \%$ and $81.2 \%$, respectively. Specimens of DB group and DC group also confirmed this trend. When the drop weight changed from $230 \mathrm{~kg}$ to $330 \mathrm{~kg}$, the duration times for specimens of DA group, DB group, and DC group were prolonged by $24.3 \%, 15.4 \%$, and $29.2 \%$, respectively. Meanwhile the corresponding average loads were increased by $98.9 \%, 49.5 \%$, and $21.2 \%$, respectively. It is noted that the growth rates of average force tended to slow down, for the impact case with a higher hollow ratio. However, the average load was almost unchanged when the drop weight varied from $330 \mathrm{~kg}$ to $430 \mathrm{~kg}$.

The impact force responses with different drop weights are shown in Figure 11 and Table 1. The effect of the hollow ratio on impact force can be concluded. It is evident that RC pier with a higher hollow ratio suffers smaller peak impact force due to the relatively low contact stiffness and overall stiffness. The maximum impact loads for specimens DB20I and DC20I were $21.5 \%$ and $60.7 \%$ lower than that of specimen DA20I, respectively. With the impact case of $M=330 \mathrm{~kg}$, the peak impact force values for specimens of DA group, DB group, and DC group were $163.85 \mathrm{kN}$, $91.84 \mathrm{kN}$, and $63.78 \mathrm{kN}$, respectively. The peak impact loads of specimens DB20II and DC20II were $56.1 \%$ and $38.9 \%$ of the corresponding solid pier, respectively. The peak impact force of specimen DB20III was $130.27 \mathrm{kN}$, which was $29.9 \%$ lower than specimen DA20III. The mean impact force exhibited small variations with the collision case of $\eta=0$ and $\eta=0.4$, regardless of $N=20$ or $N=30$. But an apparent drop of average force emerged, as the hollow ratio changed from 0.4 to 0.6 . Results indicate that a smaller hollow ratio (i.e., $\eta=0,0.4$ ) produces minor effect on the average impact load, but a relatively large hollow ratio (i.e., $\eta=0.6$ ) can significantly decrease the average impact load. The effect of the hollow ratio on average impact force was similar to that on static ultimate load.

When the total longitudinal reinforcements varied from 20 to 30, the stiffness of the specimens became larger. Consequently, the peak and mean impact force enlarged, and the duration time was reduced, as shown in Figures 10 and 11(c) and Table 1. For specimens DA20III and DA30III, the peak impact force values were $185.90 \mathrm{kN}$ and $254.20 \mathrm{kN}$, respectively, increasing by $36.7 \%$. Meanwhile the corresponding average force increased by $42.3 \%$, and the related 

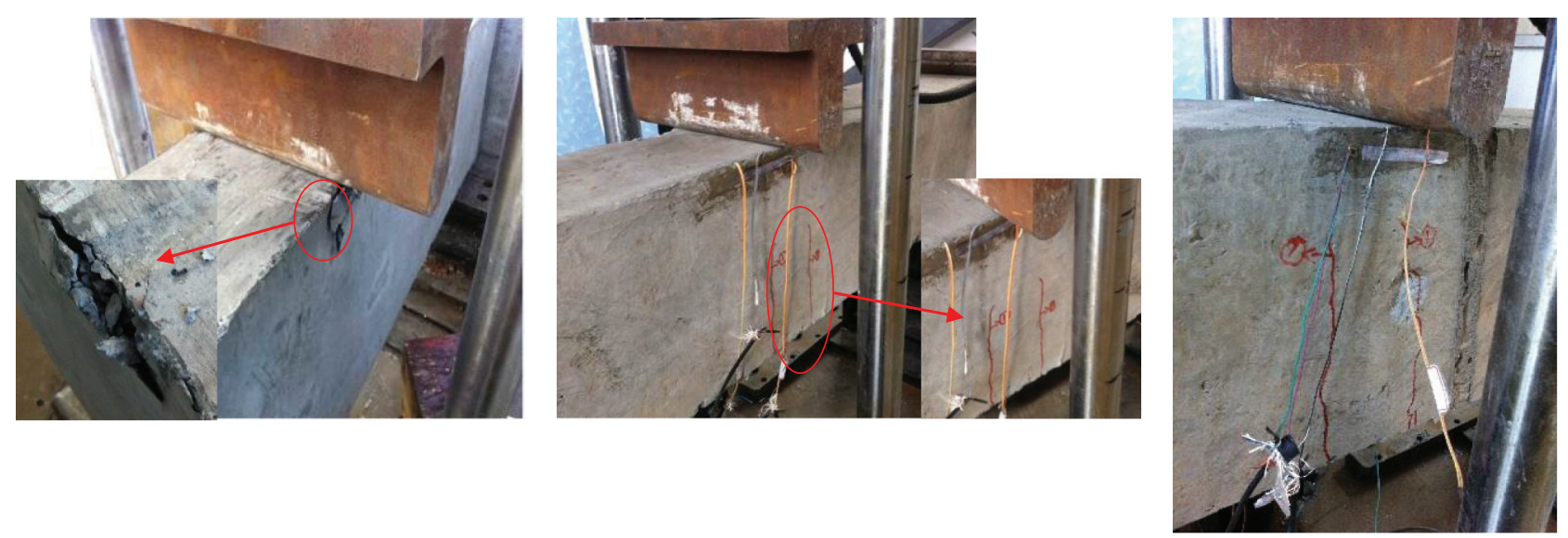

(a)

(b)

(c)

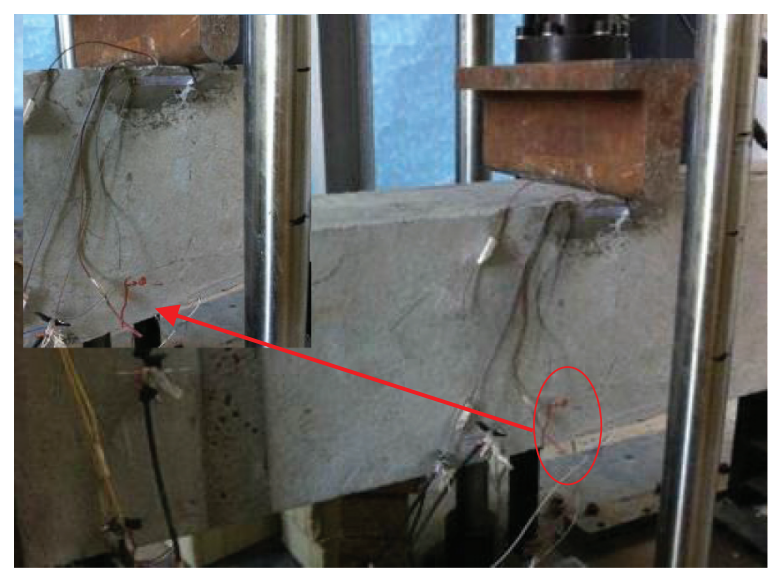

(d)

FIgURE 7: Failure modes of solid piers under impact loading. (a) DA20I. (b) DA20II. (c) DA20III. (d) DA30III.

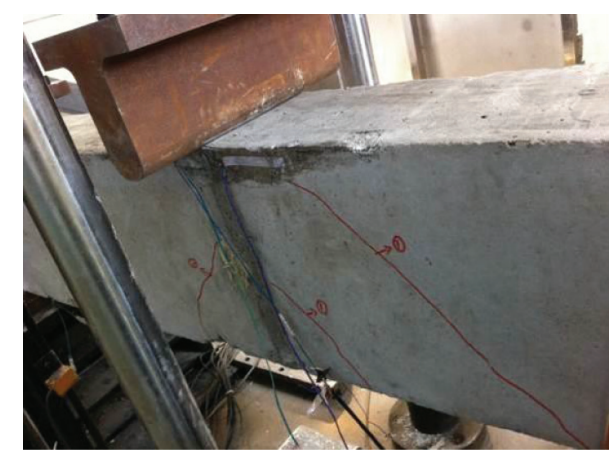

(a)

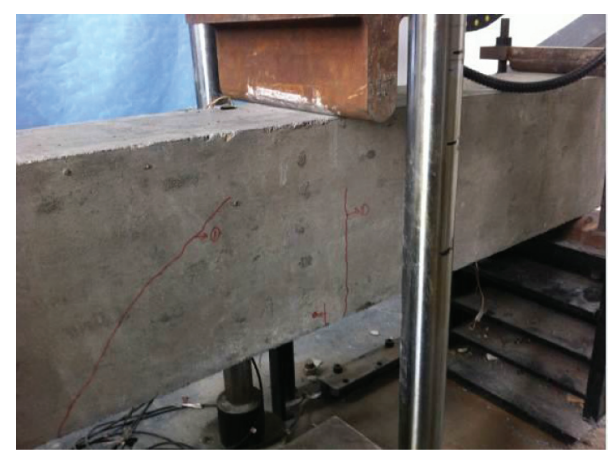

(b)

FIgURE 8: Continued. 


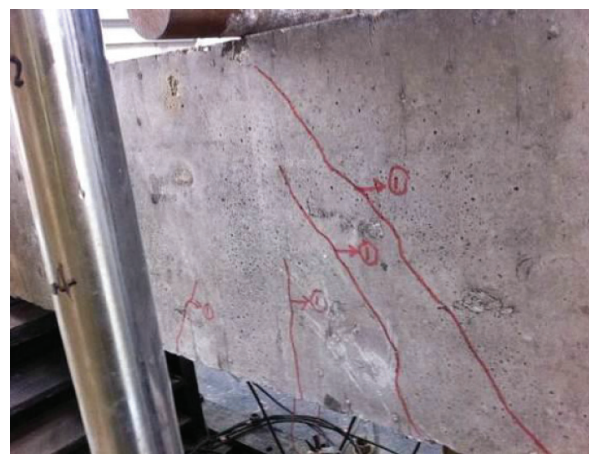

(c)

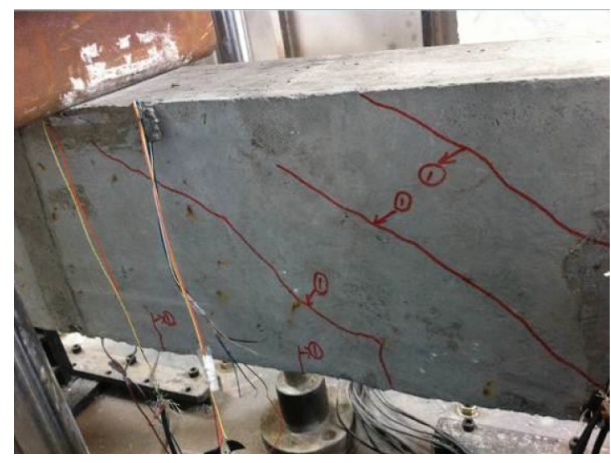

(d)

Figure 8: Failure modes of hollow piers under impact loading $(\eta=0.4)$. (a) DB20I. (b) DB20II. (c) DB20III. (d) DB30III.

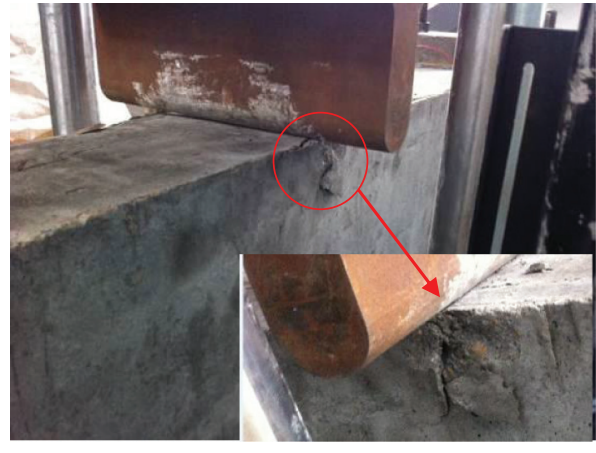

(a)

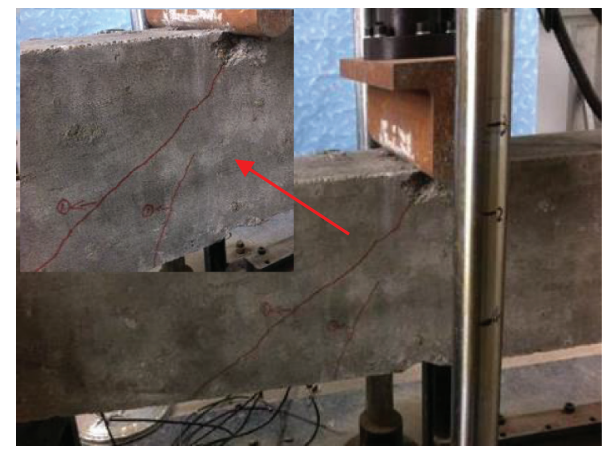

(b)

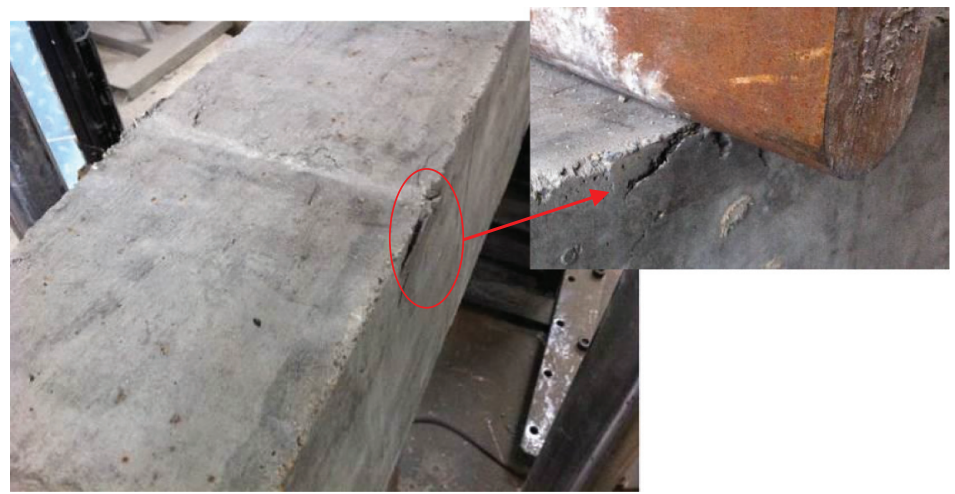

(c)

FIGURE 9: Failure modes of hollow piers under impact loading $(\eta=0.6)$. (a) DC20I. (b) DC20II. (c) DC30I.

duration time was slightly shortened. For specimens from DB group and DC group varying the longitudinal rebars, the ultimate impact loads were increased by $2.85 \%$ and $45.6 \%$, respectively. However, the mean impact force values were increased by $48.9 \%$ and $43.8 \%$, respectively.

From the impact results, it can be concluded that the impact energy (i.e., the drop weight) and the hollow ratio as well as the amount of longitudinal reinforcements had a significant effect on the peak force. With the case of $\eta=0$ and $\eta=0.4$, or the case of $M=330 \mathrm{~kg}$ and $M=430 \mathrm{~kg}$, the average load had a relatively small variation. When the drop weight varied from $230 \mathrm{~kg}$ to $330 \mathrm{~kg}$, or the hollow ratio changed from 0.6 to 0.4 , the average load was substantially enhanced.
An increase of the longitudinal reinforcement led to the promotion of the peak and mean impact force.

\section{Finite Element Analysis of RC Piers under Impact Loading}

4.1. Finite Element Model. Numerical models of drop impact on RC piers were established by the explicit finite element program ANSYS/LS-DYNA [38], as shown in Figure 12. A mesh size of $10 \mathrm{~mm}$ was used for the RC piers. This element size was selected based on mesh sensitivity analysis. The longitudinal and transverse rebars were discretized into $10 \mathrm{~mm}$ long beam elements. The drop hammer and the 


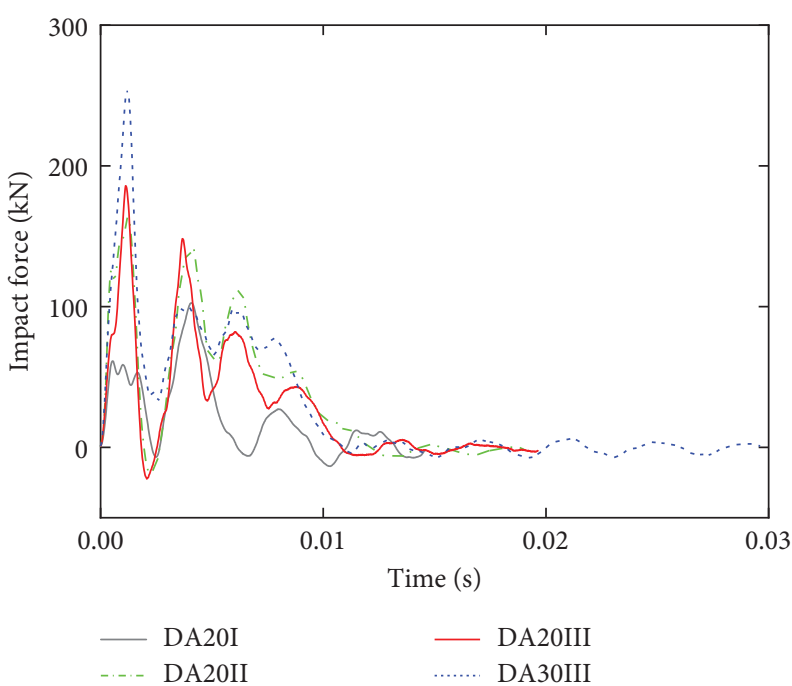

(a)

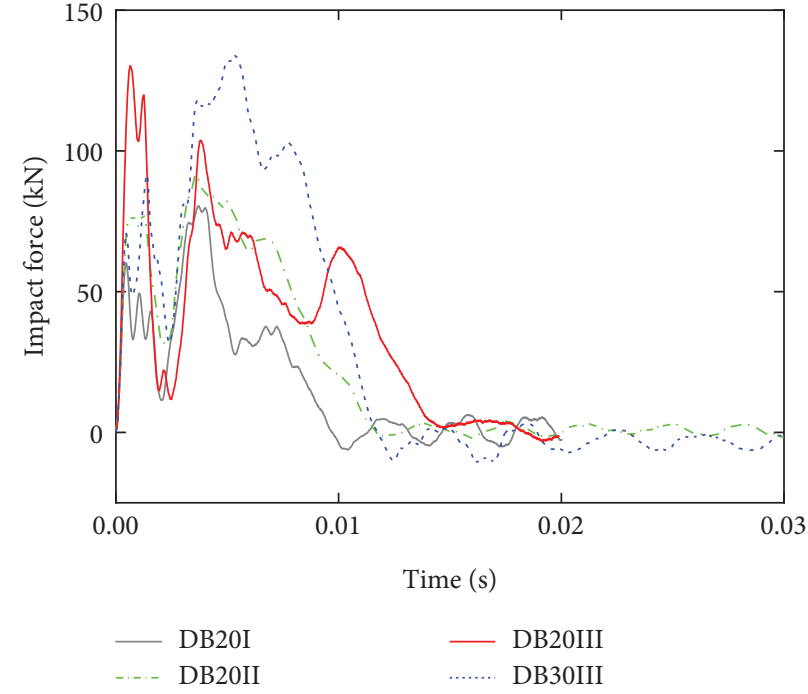

(b)

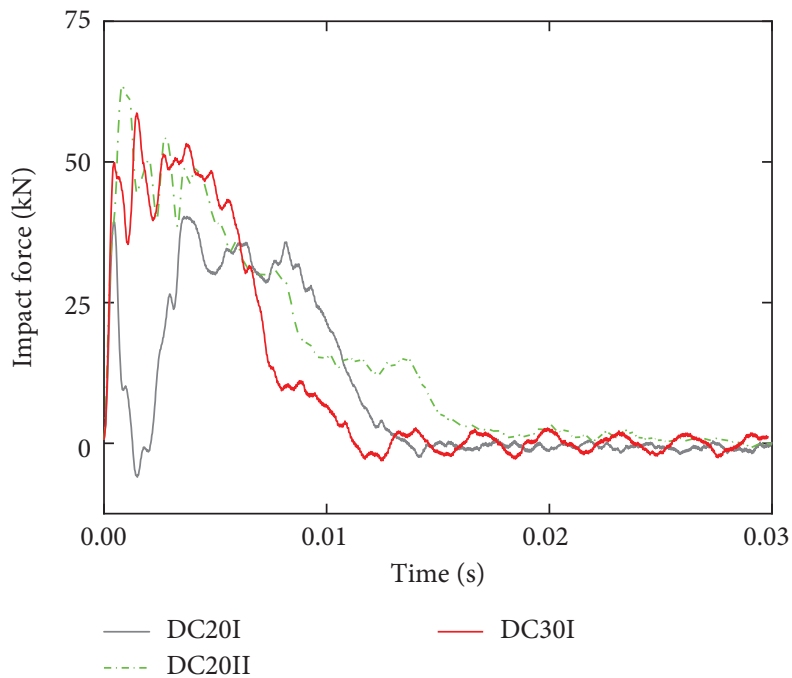

(c)

FIGURE 10: Impact force-time curves for piers with different hollow ratios. (a) $\eta=0$. (b) $\eta=0.4$. (c) $\eta=0.6$.

support rollers were meshed with a minimum mesh size of $6 \mathrm{~mm}$ and a maximum mesh size of $10 \mathrm{~mm}$. The pier foot was prevented from moving in all directions. The support rollers were simulated with constrained vertical displacement but free rotation. The initial velocity was assigned to the drop hammer. For specimen DB20III, the drop hammer, the concrete pier, and the support rollers were modeled using 84038, 130680, and 2112 eight-node solid hexahedron elements, respectively. The numerical models for other specimens differed in the total element number of the drop hammer, the concrete pier, and the reinforcements, due to the variations of the drop weight, the hollow ratio, and the amount of rebars.

The contact surfaces between each part were carefully defined. Both surface-to-surface and node-to-surface contact algorithms were employed. The former algorithm was used to model the interactions between the loading impactor, the support rollers, and the RC pier, whereas the latter algorithm was selected for the contact between the steel rebars and the drop hammer. The dynamic and static coefficients of friction were both set as $0.3[39,40]$.

4.2. Material Models. The plastic kinematic model ( *MAT_3) from LS-DYNA material library [38] was selected for the drop hammer and the longitudinal and transverse rebars. The strain rate effect was considered by the Cowper-Symonds model. The main parameters were defined as follows: strain rate parameter $C=40.4 \mathrm{~s}^{-1}$, strain rate parameter $P=5$ [41], strain hardening parameter $\beta=0$, and yield stress for reinforcing bars $\sigma_{0}=310 \mathrm{MPa}$.

The continuous surface cap model ( $*$ MAT_159) [38] was employed to represent the nonlinear behavior of concrete pier. This material model was validated to predict the dynamic behavior of RC structures under low-velocity impact loading $[11,21,41]$. The main parameters were 


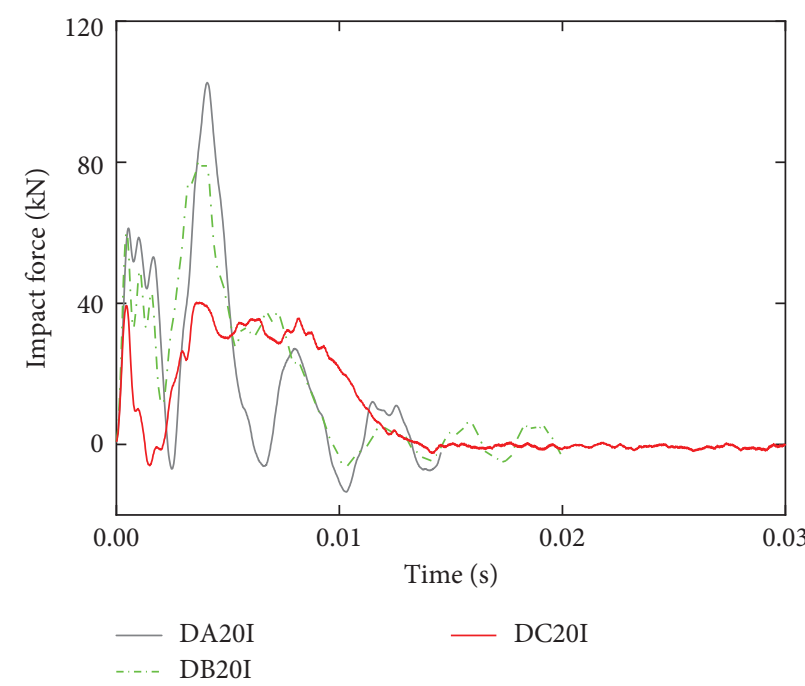

(a)

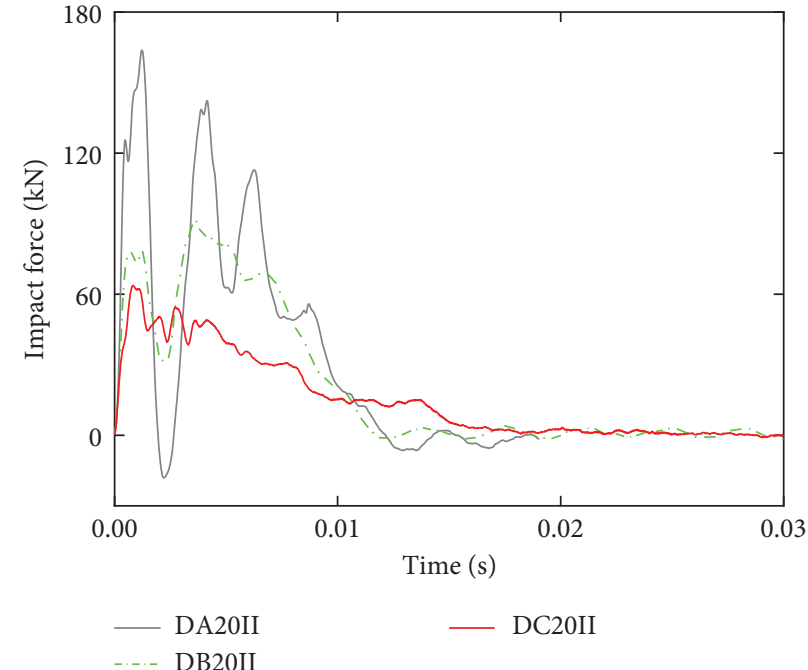

(b)

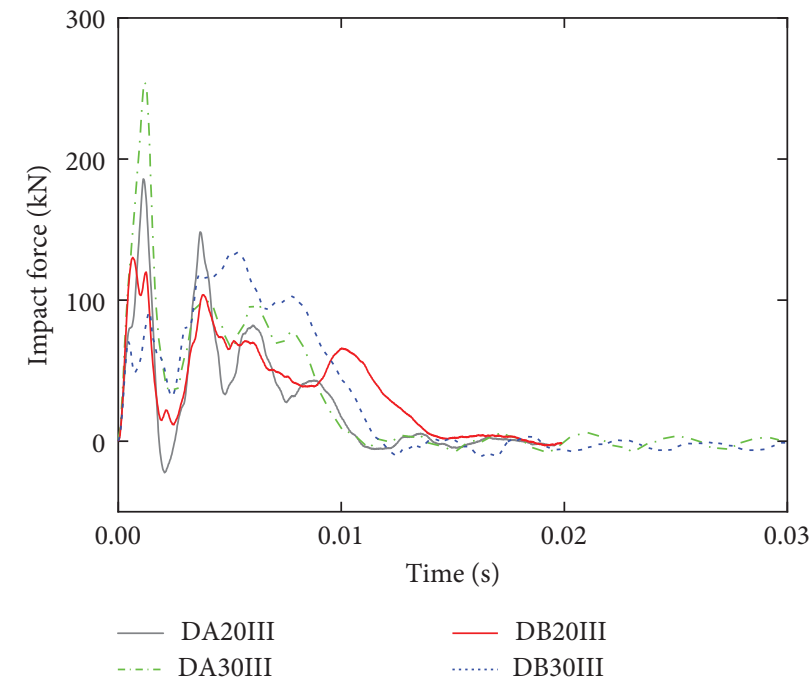

(c)

FIGURE 11: Impact force-time curves for piers with different drop weights. (a) $M=230 \mathrm{~kg}$. (b) $M=330 \mathrm{~kg}$. (c) $M=430 \mathrm{~kg}$.

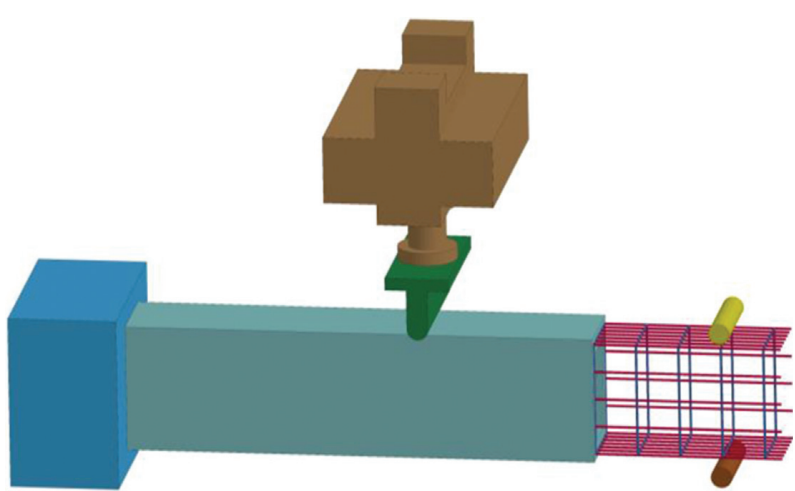

(a)

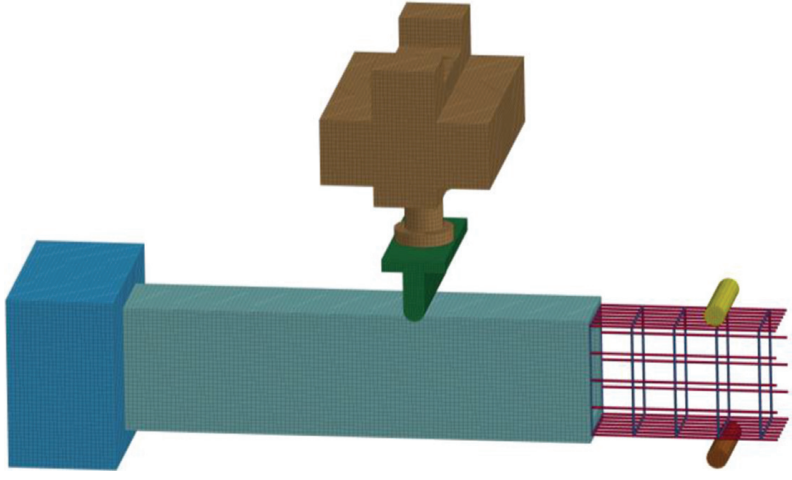

(b)

Figure 12: Numerical model of specimen DB20III. (a) Geometric configuration. (b) Finite element meshing. 


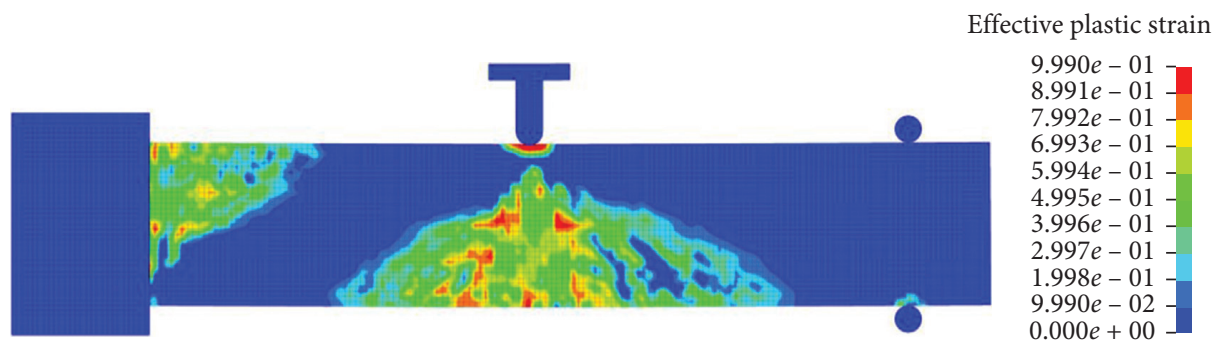

(a)

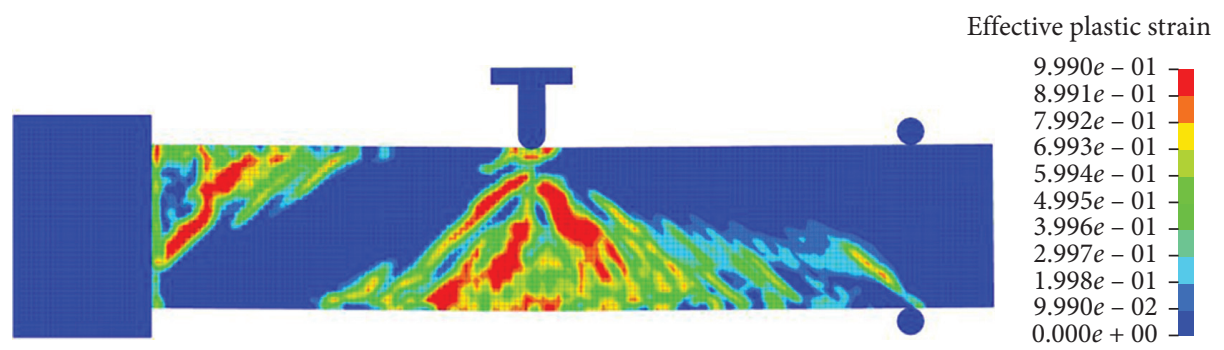

(b)

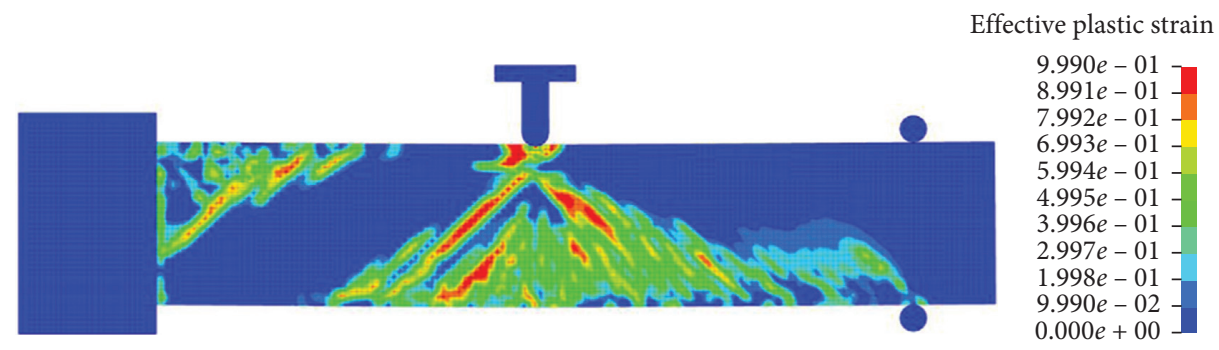

(c)

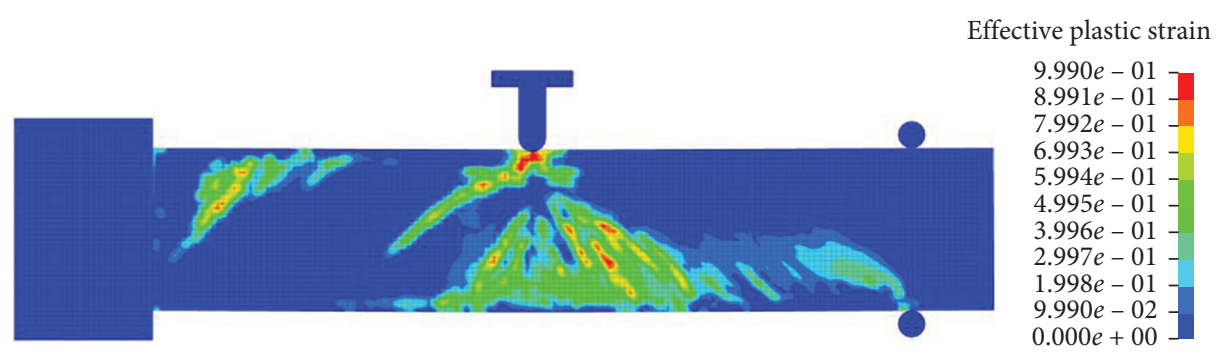

(d)

FIgURE 13: Numerically predicted concrete damage contours. (a) DA20II. (b) DB20III. (c) DB30III. (d) DC20II.

automatically generated by defining the unconfined cylinder compressive strength and aggregate size with a value of $24 \mathrm{MPa}$ and $10 \mathrm{~mm}$, respectively. The erode parameter controlling element erosion was 1.05.

MAT_RIGID ( * MAT_20) [38] was used to model the support rollers. Young's modulus and Poisson's ratio of the steel material were defined since unrealistic values may result in numerical problems in contact.

4.3. Comparisons of the Numerical and Experimental Results. Figure 13 shows the simulated concrete damage contours for the representative specimens. Effective plastic strain ranged from 0 (blue) to 1 (red). Vertical cracks, diagonal shear cracks, and local crushing of concrete were reasonably predicted. The predicted damage distribution was basically consistent with that of the experimental results.

Figure 14 illustrates the comparisons of the simulated and experimental impact force histories. The predicted load curves generally exhibited a similar shape with the experimental results, in spite of some deviations in the peak value of feature points. The numerical results tend to underestimate the peak force and the impact duration except for specimen DC20II. The average loads obtained from the predicted force-time curves for specimens DA20II, DB20III, DB30III, and DC20II were $53.27 \mathrm{kN}, 54.49 \mathrm{kN}, 65.96 \mathrm{kN}$, and $26.56 \mathrm{kN}$, respectively. The average loads were estimated with an error less than $11.8 \%$. 


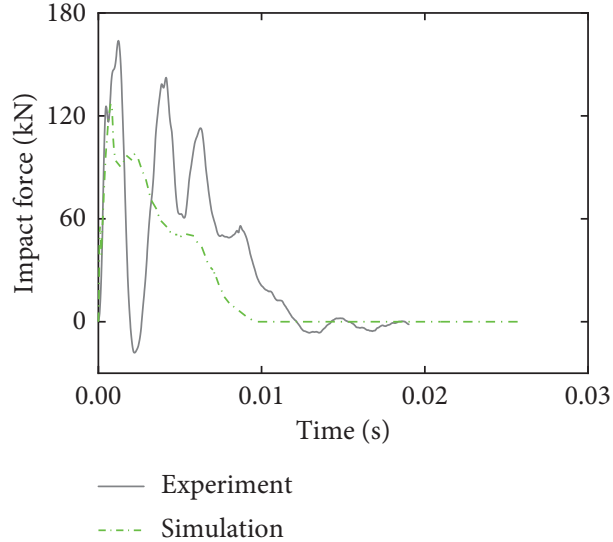

(a)

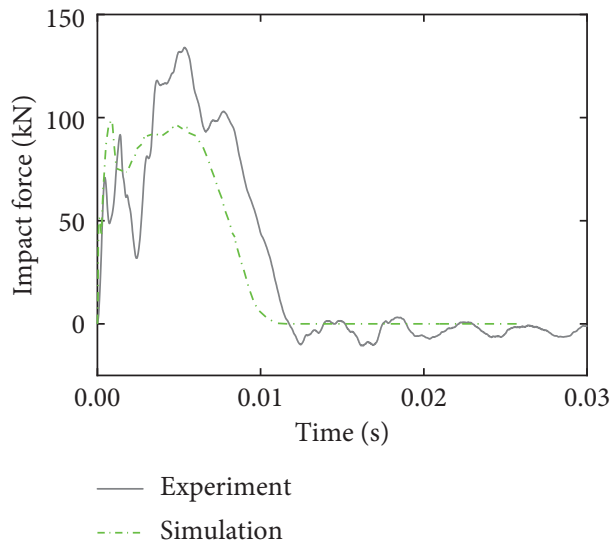

(c)

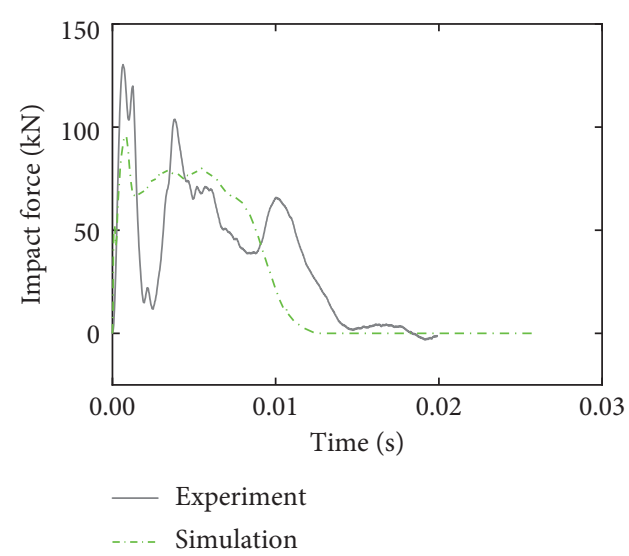

(b)

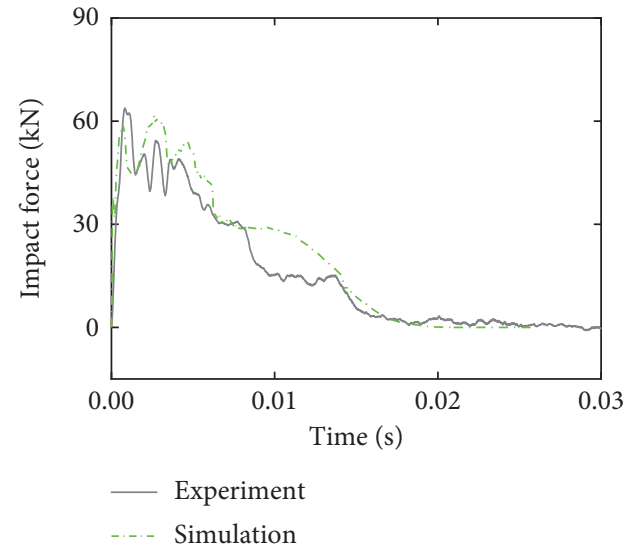

(d)

FIGURE 14: Comparisons of the impact force between the experimental and numerical results. (a) DA20II. (b) DB20III. (c) DB30III. (d) DC20II.

\section{Conclusions}

This study investigated the static and impact behavior of RC piers with different hollow ratios. Three specimens were tested under static loading. Low-velocity impact tests were carried out by a drop hammer impact system. The impact test involved eleven piers divided into DA group, DB group, and DC group. Three parameters were considered, namely, the hollow ratio, the amount of longitudinal reinforcements, and the impact energy. The damage process, failure mode, and force response were comprehensively analyzed. Numerical simulation for representative specimens was performed. The results presented in this paper support the following conclusions.

(1) The hollow ratio played a significant role in the damage process and failure mode of all RC piers. The solid RC pier under static loading exhibited the overall bending failure mode. Specimen SC20 showed only local damage. Two types of damage were observed on specimen SB20. When subjected to impact loading, RC piers with a hollow ratio of 0 and 0.4 exhibited the global failure modes, whereas failure of hollow piers of DC group was governed by the local damage near the drop hammer.
(2) The load-displacement curves indicated specimens SA20 and SB20 generally exhibited a certain ductility, while specimen SC20 showed the brittle behavior. A relatively small hollow ratio (i.e., $\eta=0,0.4$ ) had little effect on the static load capacity. However, excessive increases in the hollow ratio (i.e., $\eta=0.6$ ) significantly reduced the static ultimate load.

(3) The impact energy (i.e., the drop weight) and hollow ratio, as well as the number of longitudinal reinforcements, had a significant effect on the peak force. With the case of $\eta=0$ and $\eta=0.4$, or the case of $M=330 \mathrm{~kg}$ and $M=430 \mathrm{~kg}$, the average load had a relatively small variation. When the drop weight varied from $230 \mathrm{~kg}$ to $330 \mathrm{~kg}$, or the hollow ratio changed from 0.6 to 0.4 , the average load was substantially enhanced. The increase of the longitudinal reinforcements led to a promotion of the peak and mean impact force.

(4) According to the failure pattern and load curves under static and impact loadings, a hollow ratio of 0.4 is suggested in the preliminary design of a RC bridge pier due to a balance of structure cost and load resistant characteristic. 
(5) The numerical models of RC piers were established. The simulated failure modes and predicted load response showed satisfactory agreement with the experimental results.

\section{Data Availability}

The data used to support the findings of this study are available from the corresponding author upon request.

\section{Conflicts of Interest}

The authors declare that there are no conflicts of interest regarding the publication of this paper.

\section{Acknowledgments}

This study was supported by the National Natural Science Foundation of China (Grant no. 52078248), the Excellent Youth Foundation of Jiangsu Province (Grant no. BK20190034), and Postgraduate Research and Practice Innovation Program of Jiangsu Province (Grant no. KYCX21_1148).

\section{References}

[1] S. El-Tawil, E. Severino, and P. Fonseca, "Vehicle collision with bridge piers," Journal of Bridge Engineering, vol. 10, no. 3 , pp. 345-353, 2005.

[2] K. Wardhana and F. C. Hadipriono, "Analysis of recent bridge failures in the United States," Journal of Performance of Constructed Facilities, vol. 17, no. 3, pp. 144-150, 2003.

[3] M. C. McVay, S. J. Wasman, G. R. Consolazio, P. J. Bullock, D. G. Cowan, and H. T. Bollmann, "Dynamic soil-structure interaction of bridge substructure subject to vessel impact," Journal of Bridge Engineering, vol. 14, no. 1, pp. 7-16, 2009.

[4] Y. Hao, H. Hao, and Z.-X. Li, "Numerical analysis of lateral inertial confinement effects on impact test of concrete compressive material properties," International Journal of Protective Structures, vol. 1, no. 1, pp. 145-167, 2010.

[5] K. Fujikake, B. Li, and S. Soeun, "Impact response of reinforced concrete beam and its analytical evaluation," Journal of Structural Engineering, vol. 135, no. 8, pp. 938-950, 2009.

[6] N. Kishi and H. Mikami, "Empirical formulas for designing reinforced concrete beams under impact loading," $A C I$ Structural Journal, vol. 109, pp. 509-519, 2012.

[7] W. Zhao, J. Qian, and P. Jia, "Peak response prediction for RC beams under impact loading," Shock and Vibration, vol. 2019, Article ID 6813693, 12 pages, 2019.

[8] L. Guo, R. Mao, Z. Liu, S. Li, G. Wu, and Z. Wang, "Dynamic large deflection response of RC beams under low-speed impact loading," Shock and Vibration, vol. 2020, Article ID 8812890, 15 pages, 2020.

[9] C. Demartino, J. G. Wu, and Y. Xiao, "Response of sheardeficient reinforced circular RC columns under lateral impact loading," International Journal of Impact Engineering, vol. 109, pp. 196-213, 2017.

[10] W. Fan, B. Liu, and G. R. Consolazio, "Residual capacity of axially loaded circular RC columns after lateral low-velocity impact," Journal of Structural Engineering, vol. 145, no. 6, Article ID 04019039, 2019.

[11] J.-B. Ye, J. Cai, Q.-J. Chen, X. Liu, X.-L. Tang, and Z.-L. Zuo, "Experimental investigation of slender RC columns under horizontal static and impact loads," Structure, vol. 24, pp. 499-513, 2020.

[12] X. Zhou, H. Zhang, W. Zhang, and G. Zhang, "Study on concrete pier impact performance after implementing equal cross-section stainless steel with protection from closed-cell aluminum foam," Shock and Vibration, vol. 2020, Article ID 8869899, 17 pages, 2020.

[13] T. Yilmaz, N. Kiraç, and Ö. Anil, "Experimental investigation of axially loaded reinforced concrete square column subjected to lateral low-velocity impact loading," Structural Concrete, vol. 20, no. 4, pp. 1358-1378, 2019.

[14] J. Wei, J. Li, and C. Wu, "An experimental and numerical study of reinforced conventional concrete and ultra-high performance concrete columns under lateral impact loads," Engineering Structures, vol. 201, Article ID 109822, 2019.

[15] B. Wu and S. Xu, "Experimental study on damage evaluation of stainless steel-reinforced concrete piers under lateral impact," Advances in Mechanical Engineering, vol. 12, no. 5, pp. 1-10, 2020.

[16] Y. Sha and H. Hao, "Nonlinear finite element analysis of barge collision with a single bridge pier," Engineering Structures, vol. 41, pp. 63-76, 2012.

[17] Y. Sha and H. Hao, "Laboratory tests and numerical simulations of barge impact on circular reinforced concrete piers," Engineering Structures, vol. 46, pp. 593-605, 2013.

[18] J. Wang, Y. Song, and Z. Yu, "Impact factor method for design of bridge foundations under ship collisions," Advances in Structural Engineering, vol. 20, no. 4, pp. 534-548, 2017.

[19] H. Sharma, S. Hurlebaus, and P. Gardoni, "Performancebased response evaluation of reinforced concrete columns subject to vehicle impact," International Journal of Impact Engineering, vol. 43, pp. 52-62, 2012.

[20] R. W. Li, H. Wu, Q. T. Yang, and D. F. Wang, "Vehicular impact resistance of seismic designed RC bridge piers," Engineering Structures, vol. 220, Article ID 111015, 2020.

[21] S. Auyeung, A. Alipour, and D. Saini, "Performance-based design of bridge piers under vehicle collision," Engineering Structures, vol. 191, pp. 752-765, 2019.

[22] L. Chen, H. Wu, and T. Liu, "Shear performance evaluation of reinforced concrete piers subjected to vehicle collision," Journal of Structural Engineering, vol. 146, no. 4, Article ID 04020026, 2020.

[23] T. V. Do, T. M. Pham, and H. Hao, "Impact force profile and failure classification of reinforced concrete bridge columns against vehicle impact," Engineering Structures, vol. 183, pp. 443-458, 2019.

[24] C.-T. Cheng, J.-C. Yang, Y.-K. Yeh, and S.-E. Chen, "Seismic performance of repaired hollow-bridge piers," Construction and Building Materials, vol. 17, no. 5, pp. 339-351, 2003.

[25] A. V. Pinto, J. Molina, and G. Tsionis, "Cyclic tests on largescale models of existing bridge piers with rectangular hollow cross-section," Earthquake Engineering \& Structural Dynamics, vol. 32, no. 13, pp. 1995-2012, 2003.

[26] Z. Chen, K. T. Tse, K. C. S. Kwok, A. Kareem, and B. Kim, "Measurement of unsteady aerodynamic force on a galloping prism in a turbulent flow: a hybrid aeroelastic-pressure balance," Journal of Fluids and Structures, vol. 102, Article ID 103232, 2021.

[27] Z. Chen, X. Fu, Y. Xu, C. Y. Li, B. Kim, and K. T. Tse, “A perspective on the aerodynamics and aeroelasticity of tapering: partial reattachment," Journal of Wind Engineering and Industrial Aerodynamics, vol. 212, Article ID 104590, 2021. 
[28] Y.-K. Yeh, Y. L. Mo, and C. Y. Yang, "Seismic performance of rectangular hollow bridge columns," Journal of Structural Engineering, vol. 128, no. 1, pp. 60-68, 2002.

[29] J.-H. Lee, J.-H. Choi, D.-K. Hwang, and I.-J. Kwahk, "Seismic performance of circular hollow RC bridge columns," KSCE Journal of Civil Engineering, vol. 19, no. 5, pp. 1456-1467, 2015.

[30] Q. Qi, C. Shao, W. Wei, Z. Xiao, and J. He, "Seismic performance of railway rounded rectangular hollow tall piers using the shaking table test," Engineering Structures, vol. 220, Article ID 110968, 2020.

[31] A.-Z. Zhu, W. Xu, K. Gao, H.-B. Ge, and J.-H. Zhu, "Lateral impact response of rectangular hollow and partially concretefilled steel tubular columns," Thin-Walled Structures, vol. 130, pp. 114-131, 2018.

[32] R. Wang, L.-H. Han, X.-L. Zhao, and K. J. R. Rasmussen, "Analytical behavior of concrete filled double steel tubular (CFDST) members under lateral impact," Thin-Walled Structures, vol. 101, pp. 129-140, 2016.

[33] R. Wang, L.-H. Han, X.-L. Zhao, and K. J. R. Rasmussen, "Experimental behavior of concrete filled double steel tubular (CFDST) members under low velocity drop weight impact," Thin-Walled Structures, vol. 97, pp. 279-295, 2015.

[34] M. Li, Z. Zong, H. Hao, X. Zhang, J. Lin, and Y. Liao, "Postblast performance and residual capacity of CFDST columns subjected to contact explosions," Journal of Constructional Steel Research, vol. 167, Article ID 105960, 2020.

[35] L. Wang, Y. Liu, J. Song et al., "Deflection calculation based on SDOF method for axially loaded concrete-filled steel tubular members subjected to lateral impact," Shock and Vibration, vol. 2020, Article ID 6301018, 16 pages, 2020.

[36] S. Aghdamy, D. P. Thambiratnam, M. Dhanasekar, and S. Saiedi, "Effects of structure-related parameters on the response of concrete-filled double-skin steel tube columns to lateral impact," Thin-Walled Structures, vol. 108, pp. 351-368, 2016.

[37] W. Wang, C. Wu, Z. Liu, K. An, and J.-J. Zeng, "Experimental investigation of the hybrid FRP-UHPC-steel double-skin tubular columns under lateral impact loading," Journal of Composites for Construction, vol. 24, no. 5, Article ID 04020041, 2020.

[38] LS-DYNA, Keyword User's Manual, Livermore Software Technology Corporation, Livermore, CA, USA, 2017.

[39] H. Jiang and M. G. Chorzepa, "Case study: evaluation of a floating steel fender system for bridge pier protection against vessel collision," Journal of Bridge Engineering, vol. 21, no. 11, Article ID 05016008, 2016.

[40] Y. Sha and H. Hao, "A simplified approach for predicting bridge pier responses subjected to barge impact loading," Advances in Structural Engineering, vol. 17, no. 1, pp. 11-23, 2014.

[41] G. Gholipour, C. Zhang, and A. A. Mousavi, "Effects of axial load on nonlinear response of RC columns subjected to lateral impact load: ship-pier collision," Engineering Failure Analysis, vol. 91, pp. 397-418, 2018. 